\title{
INTERACTION OF HUMAN IMMUNODEFICIENCY AND PAPILLOMA VIRUSES: ASSOCIATION WITH ANAL EPITHELIAL ABNORMALITY IN HOMOSEXUAL MEN
}

Deoraj CAUSSY ${ }^{1,8}$, James J. GoederT ${ }^{1}$, Joel PALEFSKY ${ }^{2}$, John Gonzales ${ }^{3}$, Charles S. RabKin ${ }^{1}$, Richard A. DiGioia ${ }^{4}$, William C. SANChez ${ }^{5}$, Ronald J. Grossman ${ }^{6}$, Ginga Colclough ${ }^{7}$, Stefan Z. WIKToR ${ }^{1}$, Alexander KräMER ${ }^{1}$, Robert J. BigGaR ${ }^{1}$ and William A. BLATTNER ${ }^{1}$

${ }^{1}$ Viral Epidemiology Section, NCI, Rockville, MD 20852; ${ }^{2}$ Departments of Stomatology and Laboratory Medicine, UCSF, San Francisco, CA 94143; ${ }^{3}$ Department of Pathology, UCSF, San Francisco, CA 94143; ${ }^{4}$ George Washington University Medical Center, Washington, DC 20006; ${ }^{5}$ Private practice of medicine, Washington, DC 20008; ${ }^{6}$ Private practice of medicine, New York, NY 10016; and ${ }^{7}$ Research Triangle Institute, Washington, DC 20036, USA.

\begin{abstract}
During the 7th annual follow-up of our cohort of homosexual men in 1989, we tested the hypotheses that infection with human immunodeficiency virus (HIV) may enhance the expression of human papilloma virus (HPV) and that the development of anal epithelial abnormality is related to a biologic interaction between these two viruses. Overall, $41(39 \%)$ of the 105 men had anal swabs positive for one or more genotypes of HPV $6 / 11,16 / 18$ or $31 / 33 / 35$. Twenty-three $(53 \%)$ of the 43 HIV-positive subjects harbored HPV compared to 18 $(29 \%)$ of the 64 HIV-negative subjects $(p=0.012)$, including higher prevalence rates for HPV genotypes $16 / 18(p=0.01)$, $6 / 1$ I $(p=0.007)$, and $31 / 33 / 35(p=0.07)$. Multivariate logistic regression analysis of the HIV-positive subjects showed low $\mathrm{CD4}^{+}$cell counts to be an independent risk factor for detection of HPV $(p=0.04)$ and in particular for HPV genotypes $31 / 33 / 35(p=0.02)$ and $6 / 11(p=0.07)$. In contrast, similar analysis of the HIV-negative subset showed that a positive antibody test for syphilis was associated with HPV $(p=0.03)$. Anal epithelial abnormalities were found in 13 (14\%) of 92 technically adequate cytologic smears and were strongly associated with detection of any HPV genotypes by the dot-blot method $(p=0.01)$, and in particular with HPV genotypes $6 / 11$ $(p=0.001)$. None of 15 subjects with HPV detected only by PCR had anal epithelial abnormality. We propose a viral interaction model, in which HIV-related immune deficiency allows reactivation of HPV, with a subsequent or concomitant appearance of epithelial abnormality.
\end{abstract}

The human papillomaviruses (HPV) include at least 60 genotypes and represent an important group of human pathogens (Koutsky et al., 1988). Although some genotypes of HPV may be considered benign, as they cause common dermal warts (Jablonska et al., 1985), genotypes 16, 18, 31, 33 and others have been implicated in the pathogenesis of squamous epithelial neoplasms (Ostrow et al., 1987), including cervical dysplasia and invasive cervical cancer (Koutsky et al., 1988), anal carcinoma (zur Hausen, 1989b; Beckman et al., 1989), and perhaps bronchial carcinoma (Byme et al., 1987; Syrjanen et al., 1987). Furthermore, HPV infection of the ano-genital tract is frequent in both males and females, and some HPV are sexually transmitted (Koutsky et al., 1988). In males, HPV genotypes 6 and 11 have been detected in urethral specimens (Grussendorf-Conen et al., 1987), and HPV genotypes 2 and 5 have been detected in semen samples (Ostrow et al., 1986). A high prevalence of HPV genotypes 16 and 33 has also been detected in colposcopically directed biopsies from lesions of penile intra-epithelial neoplasia (Barasso et al., 1989).

The expression and detection of HPV are modulated by the immune status of the host. For example, the mild and transient immunodeficiency of pregnancy is associated with a concomitant increase in HPV prevalence (Schneider et al., 1987). Similar trends have been seen with iatrogenic immune suppression in renal allograft patients (Alloub et al., 1989) and in homosexual men with human immunodeficiency virus (HIV) infection (Frazer et al., 1986). Taken together, these observations imply that HIV-associated immunosuppression may result in an enhanced expression of HPV. Consequently, we evaluated anal HPV infection in a cohort of homosexual men to test the hypothesis that co-infection with HIV may enhance the expression of HPV. In addition, we evaluated whether the development of anal epithelial abnormality is related to a biologic interaction between these two viruses.

\section{MATERIAL AND METHODS}

\section{Subjects and study design}

During May and June of 1982, we initiated a prospective cohort study, enrolling 245 homosexual and bisexual men who were consecutive patients of one primary care physician in Manhattan, NY, and 2 primary care physicians in Washington, DC. Enrolled subjects were re-evaluated at approximately yearly intervals. Previous reports have provided details of enrolment and follow-up procedures; demographic, drug use, and sexual practice data; and rates and risk factors for HIV and AIDS (Goedert et al., 1984, 1985a,b, 1987; Wiktor et al., 1990). As sexual practices had markedly changed between 1982 and 1989, we analyzed associations with levels of sexual activity and smoking (at least 1 cigarette per day) at time of enrolment (1982) questionnaire because we expected that the pre-1982 behavior would be more indicative of outcome. The current analysis included the 105 subjects from whom adequate samples for HPV testing were obtained during the 1989 evaluation and included current (1989) $\mathrm{CD}^{+}$and $\mathrm{CD} 8^{+}$lymphocyte counts determined by flow cytometry (Goedert et al., $1985 a$ ).

\section{Collection of specimens}

HIV, hepatitis B and syphilis antibodies were measured by standard techniques (Goedert et al., 1987). Epithelial cells from the transformation zone of the ano-rectal junction were collected by dacron swabs that were wetted in saline, directly inserted to the ano-rectal junction and gently rotated before being withdrawn. The first swab was smeared on a clean glass slide, sprayed immediately with a water-soluble fixative for exfoliative cytology (Clay Adams, Becton Dickinson, Parsippany, NJ), and read later for cytologic abnormalities. Second and third swabs were collected similarly, transferred to transport media (Virapap, Life Technologies, Gaithersburg, MD), and kept at $4^{\circ} \mathrm{C}$ for 2 to $18 \mathrm{hr}$, when they were frozen at $-20^{\circ} \mathrm{C}$ until testing.

\section{Detection and typing of HPV DNA}

The presence of HPV was detected by dot blot hybridization and the polymerase-chain reaction (PCR). Commercially available dot blot hybridization kits (Virapap and Viratype, Life Technologies) were used to screen for HPV and for detection

${ }^{8}$ To whom reprint requests should be sent, at Viral Epidemiology Section, $\mathrm{NCl}, 6130$ Executive Blvd, EPN/434, Rockville, MD 20852, USA.

Received: March 5, 1990. 
of specific HPV genotypes $6 / 11,16,18,31,33$ and 35 , following the manufacturer's instructions.

PCR was performed directly on the same virus transport medium. Following the protease digestion step of the dot blot, $100 \mu \mathrm{l}$ of the transport medium was precipitated with $100 \%$ ethyl alcohol and $1.2 \mathrm{M}$ sodium acetate ( $\mathrm{pH}$ 5.2) overnight at $-20^{\circ} \mathrm{C}$. The precipitated DNA was dried under vacuum and redissolved in $100 \mu \mathrm{l}$ of sterile distilled water. Prior to use for PCR, the target DNA was denatured by boiling at $100^{\circ} \mathrm{C}$ for 5 $\mathrm{min}$, followed by cooling for $15 \mathrm{~min}$ on ice. Specific primer pairs, corresponding to the E6 region of the HPV genomes, were designed to detect the presence of HPV 6, 11, 16, 18, 31 and 33 sequences. Amplification was carried out in a DNA Thermal Cycler (Perkin-Elmer/Cetus, Emeryville, CA) for 30 cycles. The reaction was carried out in $50 \mu \mathrm{l}$ final volume consisting of $20 \mu \mathrm{l}$ of denatured target DNA, 2.5 units of the enzyme Taq polymerase and 50 picomole of HPV primer pairs in a PCR buffer. The composition of the PCR buffer was 10 $\mu \mathrm{M}$ of each of dATP, dGTP, dCTP, $2.5 \mathrm{~mm}$ magnesium chloride, $10 \mathrm{~mm}$ Tris-hydrochloride ( $\mathrm{pH} 8.3$ ), $50 \mathrm{~mm} \mathrm{KCl}, 0.1$ $\mathrm{mg} / \mathrm{ml}$ of gelatin (Sigma, St Louis, MO, Catalog No 6507), $0.45 \%$ Nonidet P40 (Sigma Catalog No N6507) and $0.45 \%$ Tween 20. The reaction cycle consisted of 3 steps-primer annealing for 30 seconds at $50^{\circ} \mathrm{C}$, primer extension for $2 \mathrm{~min}$ at $37^{\circ} \mathrm{C}$ and denaturation for $1 \mathrm{~min}$ at $90^{\circ} \mathrm{C}$. Based on our experience, we amplified HPV 16 and 18 sequences in one reaction mixture and HPV 6/11, 31 and 33 in a different reaction. The integrity of the amplification reaction was monitored by the incorporation of a primer pair for the hemoglobin gene in the tube containing HPV 16 and 18 primers. The amplified product was detected by hybridization with specific HPV probes at $\mathrm{T}_{\mathrm{m}}-20$ (Caussy et al., 1988).

\section{Scoring criteria for HPV positivity}

No HPV-35 probe was available for PCR. Otherwise, dot blot and PCR were done on every sample for HPV genotypes $6 / 11,16,18,31,33$ and 35 . A specimen was scored positive for a given genotype of HPV if it gave a positive hybridization signal with either the dot blot kit or the PCR reaction. For the purpose of analysis and in keeping with the known biologic properties of the HPV (Koutsky et al., 1988), we categorized the results of the HPV in the following genotypes: HPV 16/18, HPV 6/11 and HPV 31/33/35. "Any" HPV denotes the presence of HPV 6/11, HPV $16 / 18$ or HPV 31/33/35. To evaluate risk factors for HPV infection, samples giving positive signals in either the dot-blot or the PCR assay were considered positive. To evaluate the effect of HPV as a risk factor for epithelial abnormality, results of the dot-blot and the PCR were considered separately.

\section{Cytology}

Cytological smears were stained with the standard Papanicolaou technique and scored by a pathologist (J.G.) who had no prior knowledge of clinical or laboratory findings. Cells were examined for abnormal nuclear shape, size, chromatin pattern and overall nuclear staining (hyperchromasia). Smears were also examined for perinuclear cytoplasmic cavities characteristic of papillomavirus cytopathic effect. Smear cells showing at least 2 of the above nuclear abnormalities were considered to exhibit dysplasia, the grade of which was determined by the amount of squamous differentiation in the involved cells, with less differentiation corresponding to higher-grade dysplasia. Smear cells showing just one nuclear abnormality as well as perinuclear cytoplasmic cavities (koilocytosis) were considered to exhibit condylomatous changes. Smear cells showing just one nuclear abnormality and no other changes were classified as atypical. Smears with dysplasia, condylomatous changes or atypia were considered abnormal. All other smears that were adequately collected and fixed, including those with only anuclear squamous plaques, were considered normal.

\section{Statistical methods}

Data handling and statistical analyses were done by means of SAS software (SAS Institute, Cary, NC). Associations between HPV and risk factors were determined by contingency table analysis, and significance testing was performed by the Chi square test, except that Fisher's exact test was used if any cell frequency was below 5 . Student's $t$-test was used for continuous variables, or the Wilcoxon unpaired rank sum test was used for variables that were not normally distributed. Agreement between the 2 detection methods was computed by Kappa statistics (Fleiss, 1981). Multiple logistic regression was used to determine statistical independence of the effects of the parameters we studied. Statistical significance was assessed by considering a $p$ value of 0.05 or less in a 1-tail test.

\section{RESULTS}

The anal swabs of 41 (39\%) of the 105 homosexual men were positive for one or more genotypes of HPV, including 22 that were positive by both PCR and dot blot methods, 15 that were positive only by the PCR method, and 4 that were positive only by the dot blot method. There was moderate overall agreement between the two methods ( $\mathrm{k}=0.58, p=0.008$ ).

\section{Risk factors and markers for HPV}

Detection of anal HPV was strongly associated with HIV infection, with one or more HPV genotypes detected in 23 (53\%) of 43 HIV-positive men compared to $18(29 \%)$ of 62 HIV-negative men $(p=0.01$, Table I). As shown in Figure 1, each of the HPV genotypes was more frequent in HIV-positive than in HIV-negative men, including HPV 6/11 (33\% vs. $11 \%$, $p=0.007)$, HPV $16 / 18(20 \%$ vs. $5 \%, p=0.01)$, and HPV $31 / 33 / 35$ (39\% vs. $16 \%, p=0.07$ ). With the dot blot method, 2 men were co-infected with HPV $16 / 18$ and $31 / 33 / 35,3$ others were co-infected with HPV $6 / 11$ and $31 / 33 / 35$, and 3 others were infected with all 3 HPV genotype groups. These 8 men were all HIV-positive. With the PCR method, 13 men were co-infected, including 4 who were HIV-negative. Using both tests, 22 men were infected with at least 2 genotypes of HPV.

The prevalence of anal HPV was moderately associated with hepatitis B virus $(p=0.04)$ and weakly associated with syphilis $(p=0.19$, Table I). HPV-positive men had had significantly more homosexual partners before 1982 (medians $25 \mathrm{vs}$. 13.5 per year, $p=0.04$ ) and tended toward more frequent unprotected receptive anal intercourse frequency $(10-19 \mathrm{vs}$. 5-9 per year, $p=0.12$ ). In addition, HPV prevalence tended to be higher in those who had not completed college compared to those who had completed college $(p=0.07$, Table I), but no significant associations were detected between HPV prevalence and city of enrolment, ethnic origin, age, or cigarette smoking. Subjects co-infected with HIV and HPV had slightly but not significantly lower $\mathrm{CD} 4^{+}$lymphocyte counts than did those with HIV only ( $p=0.19$, Table I); however, co-infection did not appear to affect $\mathrm{CD} 8^{+}$lymphocyte counts $(p=0.65)$. Among HIV-negative subjects, CD4 ${ }^{+}$and $\mathrm{CD} 8^{+}$ lymphocyte counts were similar in HPV-positive and HPVnegative subjects $(p \geqslant 0.78)$.

Stepwise logistic regression modelling was used to assess the relationship of each HPV genotype to the 5 following variables: current $\mathrm{CD} 4^{+}$lymphocyte count, serological evidence of syphilis or hepatitis B virus infection, and historical number of male homosexual partners and frequency of receptive anal intercourse. Due to the strong associations between HPV and HIV status, separate models were run for HIV-positive and HIV-negative men. Among the HIV-positive subjects, lower numbers of $\mathrm{CD}^{+}$lymphocytes were independently associated 
TABLE I - PREVALENCE OF ANY HPV GENOTYPE BY SELECTED DEMOGRAPHIC AND EXPOSURE CHARACTERISTICS

\begin{tabular}{|c|c|c|c|}
\hline Characteristic & $\begin{array}{l}\text { Number } \\
\text { of HPV } \\
\text { negative }\end{array}$ & $\begin{array}{l}\text { Number of } \\
\text { (\%) HPV } \\
\text { positive }\end{array}$ & $p$ value \\
\hline $\begin{array}{l}\text { HIV status } \\
\text { Positive } \\
\text { Negative }\end{array}$ & $\begin{array}{l}20 \\
44\end{array}$ & $\begin{array}{l}23(53 \%) \\
18(29 \%)\end{array}$ & 0.01 \\
\hline $\begin{array}{l}\text { Anti-hepatitis B core antigen } \\
\text { Positive } \\
\text { Negative }\end{array}$ & $\begin{array}{l}41 \\
23\end{array}$ & $\begin{array}{r}33(45 \%) \\
7(23 \%)\end{array}$ & 0.04 \\
\hline $\begin{array}{l}\text { Syphilis serology } 2 \\
\text { Positive } \\
\text { Negative }\end{array}$ & $\begin{array}{r}9 \\
54\end{array}$ & $\begin{array}{l}10(53 \%) \\
31(36 \%)\end{array}$ & 0.19 \\
\hline $\begin{array}{l}\text { Number of homosexual } \\
\text { partners in } 1982 \text { (median) }\end{array}$ & 13.5 & 25 & 0.04 \\
\hline $\begin{array}{l}\text { Number of receptive } \\
\text { anal intercourse acts } \\
\text { in } 1982 \text { (median) }\end{array}$ & $5-9$ & $10-19$ & 0.12 \\
\hline $\begin{array}{l}\text { Completed college education } \\
\text { Yes } \\
\text { No }\end{array}$ & $\begin{array}{l}51 \\
13\end{array}$ & $\begin{array}{l}26(34 \%) \\
15(54 \%)\end{array}$ & 0.07 \\
\hline $\begin{array}{l}\text { City-New York } \\
\text { Washington }\end{array}$ & $\begin{array}{l}13 \\
51\end{array}$ & $\begin{array}{l}11(46 \%) \\
30(37 \%)\end{array}$ & 0.44 \\
\hline $\begin{array}{l}\text { Race-White } \\
\text { Non-white }\end{array}$ & $\begin{array}{r}58 \\
6\end{array}$ & $\begin{array}{r}35(38 \%) \\
6(50 \%)\end{array}$ & 0.41 \\
\hline Age (mean) & 41 & 40 & 0.56 \\
\hline $\begin{array}{r}\text { Cigarette smoker-Yes } \\
- \text { No }\end{array}$ & $\begin{array}{l}20 \\
44\end{array}$ & $\begin{array}{l}11(35 \%) \\
30(41 \%)\end{array}$ & 0.63 \\
\hline $\begin{array}{l}\text { HIV-positive subjects } \\
\text { CD4 counts } \\
\text { (mean cells } / \mu \mathrm{l}) \\
\text { CD8 counts } \\
\text { (mean cells } / \mu \mathrm{l})\end{array}$ & 630 & 515 & 0.19 \\
\hline $\begin{array}{l}\text { HIV-negative subjects } \\
\text { CD4 counts } \\
\text { (mean cells } / \mu l \text { ) } \\
\text { CD8 counts } \\
\text { (mean cells } / \mu l \text { ) }\end{array}$ & 1103 & 1151 & 0.95 \\
\hline
\end{tabular}

${ }^{1}$ Chi-square for proportions, t-test for means, or Wilcoxon rank sum test. $-{ }^{2}$ Microhemagglutination for Treponema pallidum.

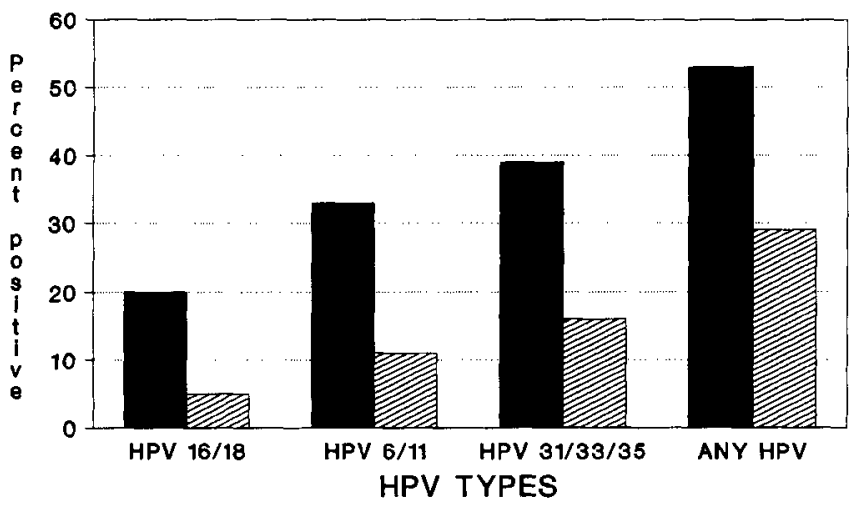

HIV positive $n=43$ HIV negative $n-62$

FIgURE 1 - Prevalence of specific genotypes of human papillomaviruses (HPV) detected in anal swabs from 105 homosexual men, by the subjects' human immunodeficiency virus (HIV) status.

with the detection of one or more HPV genotypes $(p=0.04)$, after adjusting for the number of sexual partners, anal intercourse and syphilis (Table II). This adjusted association with CD4 counts was strongest with HPV genotypes 31/33/35 $(p=0.02)$, weaker with HPV genotypes $6 / 11(p=0.07)$,
TABLE II - MULTIVARIATE ANALYSIS OF RISK FACTORS FOR HPV GENOTYPES AMONG HIV-POSITIVE SUBJECTS

\begin{tabular}{|c|c|c|c|}
\hline $\begin{array}{c}\text { Dependent } \\
\text { variables }\end{array}$ & $\begin{array}{c}\text { Independent } \\
\text { variables }\end{array}$ & $x^{21}$ & $p$-values \\
\hline $\begin{array}{l}\text { One or more } \\
\text { HPV genotypes }\end{array}$ & $\begin{array}{l}\text { CD4 counts } \\
\text { Sexual partners } \\
\text { Syphilis } \\
\text { Frequency of } \\
\quad \text { receptive anal } \\
\text { intercourse }\end{array}$ & $\begin{array}{l}4.46 \\
0.02 \\
0.28 \\
0.18\end{array}$ & $\begin{array}{l}0.04^{2} \\
0.89 \\
0.59 \\
0.67\end{array}$ \\
\hline $\begin{array}{l}\text { HPV 6/11 } \\
\text { genotypes }\end{array}$ & $\begin{array}{l}\text { CD4 counts } \\
\text { Sexual partners } \\
\text { Syphilis } \\
\text { Frequency of } \\
\quad \text { receptive anal } \\
\quad \text { intercourse }\end{array}$ & $\begin{array}{l}3.32 \\
0.38 \\
0.18 \\
0.02\end{array}$ & $\begin{array}{l}0.07 \\
0.54 \\
0.67 \\
0.89\end{array}$ \\
\hline $\begin{array}{l}\text { HPV 16/18 } \\
\text { genotypes }\end{array}$ & $\begin{array}{l}\text { CD4 counts } \\
\text { Sexual partners } \\
\text { Syphilis } \\
\text { Frequency of } \\
\quad \text { receptive anal } \\
\quad \text { intercourse }\end{array}$ & $\begin{array}{l}0.01 \\
0.62 \\
0.55 \\
2.68\end{array}$ & $\begin{array}{l}0.93 \\
0.43 \\
0.46 \\
0.10\end{array}$ \\
\hline $\begin{array}{l}\text { HPV 31/33/35 } \\
\text { genotypes }\end{array}$ & $\begin{array}{l}\text { CD4 counts } \\
\text { Sexual partners } \\
\text { Syphilis } \\
\text { Frequency of } \\
\quad \text { receptive anal } \\
\text { intercourse }\end{array}$ & $\begin{array}{l}5.32 \\
1.40 \\
0.02 \\
0.61\end{array}$ & $\begin{array}{l}0.02^{2} \\
0.23 \\
0.89 \\
0.43\end{array}$ \\
\hline
\end{tabular}

${ }^{1}$ Associated with the independent variable for relative contribution to the model. Arrows indicate direction of associations. ${ }^{2}$ Statistically significant at $p=0.05$. Separate models were nu for each viral genotype using continuous independent variables except for syphilis (antibody to Treponema pallidum) and hepatitis B virus (antibody to hepatitis B core antigen).

and not detectable with HPV genotypes $16 / 18(p=0.93$, Table II). The only other independent association in the HIVpositive men was a trend toward higher frequency of anal intercourse with HPV $16 / 18(p=0.10$, Table II), which was stronger (i.e., $p<0.01$ ) after serological evidence of hepatitis $B$ virus was added to this model. Among the HIV-negative men, a multivariate logistic regression model demonstrated a significant association between detection of any HPV and a positive syphilis serology $(p=0.03)$ but not with CD4 counts, anal sex or sexual partners $(p>0.18)$. This multivariate association was particularly strong for syphilis with HPV $31 / 33 / 35(p=0.01)$.

\section{Risk factors for anal epithelial abnormality}

Thirteen (12\%) of the anal cytologic smears obtained were technically unsatisfactory and could not be interpreted. Of the 92 smears that could be interpreted, $13(14 \%)$ demonstrated epithelial abnormality, including 1 with dysplasia, 3 with condylomatous changes, and 9 with atypia. Nine (24\%) of the 37 HIV-positive men had epithelial abnormality, compared to $4(7 \%)$ of the $55 \mathrm{HIV}$-negative men $(p=0.03)$. Cigarette smoking had a weaker association, with epithelial abnormality in $6(21 \%)$ of 28 smokers compared to $7(11 \%)$ of 65 nonsmokers $(p=0.15)$.

The prevalence of anal epithelial abnormality was dependent on both the HPV genotypes and the detection method used. Thus, when the dot blot technique was used, anal epithelial abnormality was strongly associated with HPV $(p=0.012$, Table III), particularly with genotypes $6 / 11(p=0.0014)$ and to a lesser extent with genotypes $31 / 33 / 35(p=0.063)$. However, when HPV was detectable by the PCR method only, none of the 15 subjects (4 HIV-positive and $11 \mathrm{HIV}$-negative) had an epithelial abnormality. Six men with mild abnormalities (atypia) were not positive in the HPV dot blots. Three of these men were cigarette smokers. On further assessment of statistical independence by the logistic regression technique, anal 
TABLE II - ASSOCIATION BETWEEN ABNORMAL ANAL CYTOLOGY AND DOT-BLOT METHOD OF DETECTING HPV IN 92 HIV-POSITIVE OR -NEGATIVE HOMOSEXUAL MEN

\begin{tabular}{|c|c|c|c|c|c|c|c|}
\hline \multirow[t]{2}{*}{$\begin{array}{l}\text { HPV by } \\
\text { dot blot } \\
\text { method }^{1}\end{array}$} & & \multicolumn{2}{|c|}{$\begin{array}{l}\text { HIV-negative } \\
\text { men } \\
\text { Anal cytology }\end{array}$} & \multicolumn{2}{|c|}{$\begin{array}{l}\text { HIV-positive } \\
\text { men } \\
\text { Anal cytology }\end{array}$} & \multicolumn{2}{|c|}{$\begin{array}{l}\text { All } 92 \text { men } \\
\text { Anal cytology }\end{array}$} \\
\hline & & Normal & Abnormal & Normal & Abnormal & Normal & Abnormal \\
\hline Any HPV & + & $\begin{array}{r}46 \\
5\end{array}$ & $\begin{array}{l}3 \\
1\end{array}$ & $\begin{array}{l}18 \\
10\end{array}$ & $\begin{array}{l}3 \\
6\end{array}$ & $\begin{array}{l}64 \\
15\end{array}$ & $\begin{array}{r}6 \\
7^{2}\end{array}$ \\
\hline HPV 6/11 & + & $\begin{array}{r}49 \\
2\end{array}$ & $\begin{array}{l}3 \\
1\end{array}$ & $\begin{array}{r}24 \\
4\end{array}$ & $\begin{array}{l}4 \\
5\end{array}$ & $\begin{array}{r}73 \\
6\end{array}$ & $\begin{array}{r}7 \\
6^{3}\end{array}$ \\
\hline HPV $16 / 18$ & $\overline{-}$ & $\begin{array}{r}50 \\
1\end{array}$ & $\begin{array}{l}4 \\
0\end{array}$ & $\begin{array}{r}23 \\
5\end{array}$ & $\begin{array}{l}7 \\
2\end{array}$ & $\begin{array}{r}73 \\
6\end{array}$ & $\begin{array}{r}11 \\
2\end{array}$ \\
\hline $\begin{array}{l}\text { HPV } \\
\qquad 31 / 33 / 35\end{array}$ & - & $\begin{array}{r}49 \\
2\end{array}$ & $\begin{array}{l}4 \\
0\end{array}$ & $\begin{array}{r}22 \\
6\end{array}$ & $\begin{array}{l}5 \\
4\end{array}$ & $\begin{array}{r}71 \\
8\end{array}$ & $\begin{array}{r}9 \\
4^{4}\end{array}$ \\
\hline
\end{tabular}

${ }^{1}$ By PCR, 18 subjects ( 5 with epithelial abnornality) were positive for HPV 6/11; 12 (1 with epithelial abnormality) for HPV $16 / 18 ; 16$ (1 with epithelial abnormality) for HPV $31 / 33 / 35$; and 34 ( 6 with epithelial abnomality) for any $\mathrm{HPV} \cdot \mathrm{-}^{2} p=0.012$ by Fisher's exact test. $-{ }^{3} p=0.0014$ by Fisher's exact test. $-{ }^{4} p=0.063$ by Fisher's exact test.

epithelial abnormality was strongly related to dot-blot detection of HPV $6 / 11(p<0.002)$, very weakly related to smoking $(p=0.07$ to 0.13 ), and unrelated (after adjustment for HPV status) to CD4 counts $(p>0.3)$ or HIV status $(p>0.3)$.

\section{DISCUSSION}

In our study of homosexual men, $39 \%$ had one or more genotypes of HPV detected by molecular analyses of anal swabs and $14 \%$ had epithelial abnormality on anal cytologic smears. In the presence of HIV infection, the prevalence rates of all HPV genotypes tested were increased, and in particular the prevalence rates of HPV genotypes $31 / 33 / 35$ and $6 / 11$ were inversely related to $\mathrm{CD} 4^{+}$lymphocyte counts. Furthermore, anal epithelial abnormality was more frequent with certain HPV genotypes as detected by the dot blot method.

Morphologic features indicative of HPV infection have been previously noted in anal intra-epithelial neoplasia (AIN) of HIV-infected men (Croxton et al., 1984). Scholefield et al. (1989) using DNA hybridization on colposcopically-directed anal biopsies, have reported that HPV genotypes $6 / 11$ were associated with low-grade AIN and HPV genotypes $16 / 18$ with high-grade AIN, similar to the pattern observed in cervical intra-epithelial lesions (Crum et al., 1985). Cytologic evidence of HPV infection in HIV-infected homosexual men has also been noted (Frazer et al., 1986). By a combination of molecular and cytologic methods, we have been able to confirm the presence of, and to further evaluate the relationships between, specific HPV genotypes and abnormal anal cytology. We found that the prevalence of anal epithelial abnormality was related to genotypes $6 / 11$ and to a lesser extent with HPV genotypes $31 / 33 / 35$. It is noteworthy that these associations were strongest for the dot-blot detection method, which requires a high copy number of HPV genomes (Caussy et al., 1988), and weakest for the PCR method, which does not. As there were no high-grade AIN lesions in our population, our observation on HPV 6/11 and anal epithelial abnormality is consistent with that of Scholefield et al. (1989).

HPV infections may be latent (Ferenczy et al., 1985) and the factors triggering reactivation are not fully defined although immune competence is clearly involved. For instance, the transient immune deficiency associated with pregnancy (Schneider et al., 1987) and iatrogenic immune deficiency of renal transplantation can lead to HPV reactivation (Alloub et al., 1989; Rudlinger et al., 1989). Similarly, we noted that the prevalence of HPV increased inversely with the number of $\mathrm{CD}^{+}$ lymphocytes among HIV-infected homosexual men. Since our observations suggest that epithelial abnormality is related to active replication of HPV and an increased number of copies of its genome, we postulate that HIV-related immune deficiency is not directly related to anal epithelial abnormality but rather may permit reactivation of dormant HPV (Fig. 2). In this model, epithelial abnormality is a consequence of actively replicating HPV, with perhaps some independent contribution from smoking. Our model provides a general framework for understanding the role of immune suppression in the reactivation of dormant HPV infection to induce cytologic abnormality.

Anal carcinoma is a relatively rare disease (Young et al., 1981) and the etiological role of HPV in the genesis of anal cancer (zur Hausen, 1989a), as in cervical cancer (Caussy et $a l ., 1990$ ), has been difficult to substantiate epidemiologically. If epithelial abnormality is a pre-malignant condition, then one might expect an increase in the number of cases of anal cancer among those at high risk of AIDS. In fact, the frequency of anal cancers among never-married men between 20 and 49 years of age increased 10-fold in Manhattan, New York City from 0.3 cases per year before 1977 to 3 cases per year between 1979 and 1985 (Biggar et al., 1989). In addition, increased risks have been noted for homosexual men (Daling $e t$ al., 1987; Holly et al., 1989).

Early studies linking HPV to anal carcinoma have employed cytologic (Holly et al., 1989) or immunochemical methods (Gal et al., 1987) that could not implicate the particular genotypes of HPV involved. A population-based case-control study did note that HPV 16/18, 31 and even 6/11 were associated with anal cancer (Beckman et al., 1989). HPV genotypes $16 / 18,31,33$ and 35 have been reported in cervical dysplasia, cervical carcinoma and anogenital carcinoma and are likely to be involved in the genesis of anal carcinoma (Beaudenon et al., 1986; Lorincz et al., 1986, 1987; zur Hausen, 1989). The role of HPV 6/11 in squamous-cell carcinoma remains controversial, since infection with HPV $6 / 11$ is associated with concomitant infection with other genital HPV

\section{SEXUAL EXPOSURE}

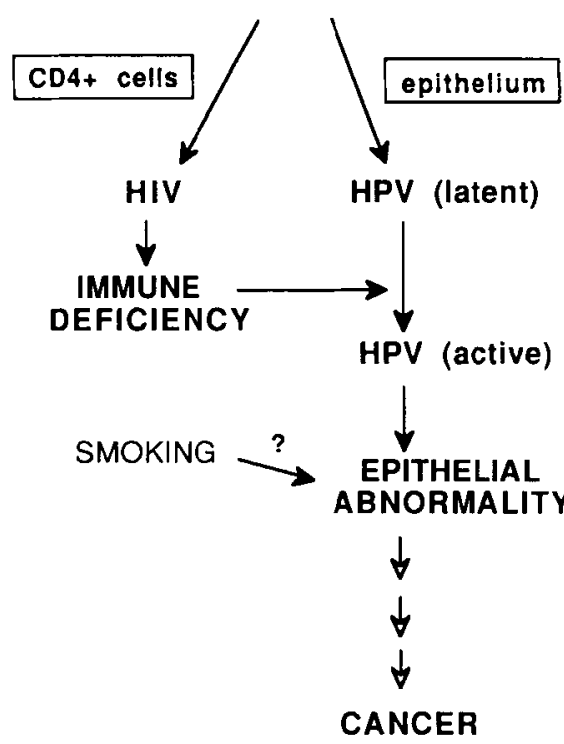

Figure 2 - Proposed model of the relationships of human immunodeficiency virus (HIV) infection, HIV-related immune deficiency, human papillomavirus (HPV) infection and activation, and epithelial abnormality. Immune deficiency appears to foster the activation of HPV, with concomitant or subsequent appearance of epithelial abnormality. Cigarette smoking may also contribute to cytologic abnormality, and the precise relationship of abnormality to cancer is unknown. 
genotypes (zur Hausen, 1989a). Nonetheless, genotypes of HPV 6/11 have been identified in a variety of squamous-cell carcinomas (Byrne et al., 1987; Kasher and Roman, 1988; Rando et al., 1986) and the oncogenic potential of this genotype should not be dismissed. Our findings indicate the need for further study of HPV genotypes in the pathogenesis of anal carcinoma.

Retrospective case-control and cross-sectional studies cannot unambiguously distinguish etiologically relevant infection with HPV from opportunistic infection of an established cancer (Caussy et al., 1990; Muñoz et al., 1988). Our finding of a high prevalence of HPV infection in a cohort not selected for the presence of anal carcinoma or epithelial abnormality, in addition to the association of certain genotypes with epithelial abnormality, support the hypothesis that one or more genotypes of HPV are etiologically involved in the pathogenesis of anal carcinoma and are not merely another opportunistic agent in HIV-infected subjects. However, only prospective followup of these types of cohorts will unambiguously establish which specific genotypes of HPV are directly or indirectly predictive of anal cancer onset.

\section{ACKNOWLEDGEMENTS}

The skilful technical assistance of the staff of Program Resources and of Ms. J. Berline, UCSF, are gratefully acknowledged. We are also grateful for data programming by Ms. S. Wilson and Dr. F. Yellin, ARC Professional Services, study management by Ms. S. Felton of the Research Triangle Institute, and helpful discussions with Dr. M. Schiffman. This work was supported in part by contract No. 1-CP-61013 with the $\mathrm{NCI}$.

\section{REFERENCES}

Alloub, M.I., BarR, B.B.B., McLaren, K.M., Smith, I.W., BunNey, M.H. and SMART, G.E., Human papillomavirus infection and cervical intraepithelial neoplasia in women with renal allografts. Brit. med. J., 298, 153-156 (1989).

Barrasso, R., DeBrux, J., Croissant, O. and Orth, G., High prevalence of papillomavirus-associated penile intraepithelial neoplasia in sexual partners of women with cervical intraepithelial neoplasia. New Engl. J. Med., 317, 916-923 (1987).

Beaudenon, S., Kremsdorf, D., Croissant, O., Jablonska, S., WAIN-HoBson, S. and ORTH, G., A novel type of human papillomavirus associated with genital neoplasia. Nature (Lond.), 321, 246-249 (1986). Beckmann, A.M., Daling, J.R., Sherman, K.J., Maden, C., Miller, B.A., CoATES, R.J., KIVIAT, N.B., MYERSON, D., Weiss, N.S., Hislop, T.G., Beagrie, M. and McDougall, J.K., Human papillomavirus infection and anal cancer. Int. J. Cancer, 43, 1042-1049 (1989).

Biggar, R.J., BurnetT, W., MrkL, J. and NasCa, P., Cancer among New York men at risk of acquired immunodeficiency syndrome. Int. $J$. Cancer, 43, 979-985 (1989).

Byrne, J.C., Tsao, M-S., Fraser, R.S. and Howley, P.M., Human papillomavirus-11 DNA in a patient with chronic laryngotracheobronchial papillomatosis and metastatic squamous-cell carcinoma of the lung. New Engl. J. Med., 317, 873-878 (1987).

Caussy, D., Marrett, L.D., Worth, A.J., McBride, M. and Rawls, W.E., Human papillomavirus in cervical intraepithelial neoplasia of women who subsequently developed invasive cancer. Canad. med. Ass. J., 142, 311-317 (1990).

Caussy, D., OrR, W., Daya, A.D., Roth, P., Reeves, W. and Rawls, W., Evaluation of methods for detection of human papillomavirus deoxyribonucleotide sequences in clinical specimens. J. clin. Microbiol., 26, 236-243 (1988).

Croxton, T., Chabon, A.B., Rorat, E. and Barash, I.M., Intraepithelial carcinoma of the anus in homosexual men. Dis. Colon Rectum, 27, 325-330 (1984)

Crum, C.P., Mitao, M., Levine, R.U. and Silverstein, S., Cervical papillomaviruses segregate within morphologically distinct precancerous lesions. J. Virol., 54, 675-681 (1985).

Daling, J.R., Weiss, N.S., Hislop, T.G., Maden, C., Coates, R.J., Sherman, K.J., AShLEY, R.L., BeAgrie, M., RYAN, J.A. and COREY, L., Sexual practices, sexually transmitted diseases and the incidence of anal cancer. New Engl. J. Med., 317, 973-977 (1987).

Ferenczy, A., Mitao, M., Nagai, N., Silverstein, S.J. and Crum, C.P., Latent papillomavirus and recurring genital warts. New Engl. J. Med., 313, 784-788 (1985).

FLEISs, J.L., Statistical methods for rates and proportions, 2nd ed., pp. 211-236, John Wiley, New York (1981).

Frazer, I.H., Medley, G., Crapper, R.M., Brown, T.C. and MACKAY, I.R., Association between anorectal dysplasia, human papillomavirus, and human immunodeficiency virus infection in homosexual men. Lancet, II, 657-660 (1986).

GAL, A.A., Meyer, P.R. and TAYLoR, C.R., Papillomavirus antigens in anorectal condyloma and carcinoma in homosexual men. J. Amer, med. Ass., 257, 337-340 (1987).

Goedert, J.J., Biggar, R.J., Melbye, M., Mann, D.L., Wilson, S., GaIL, M.H., Grossman, R.J., DiGioia, R.A., SanChez, W.C., Weiss, S.H. and BLATTNER, W.A., Effect of T4 count and cofactors on the incidence of AIDS in homosexual men infected with human immunodeficiency virus. J. Amer. med. Ass., 257, 331-334 (1987).

Goedert, J.J., Biggar, R.J., Winn, D.M., ManN, D.L., Strong, D.M., DiGioia, R.A., Grossman, R.J., SANCHEZ, W.C., KASE, R.G., Greene, M.H., Byar, D.P., Hoover, R.N. and BlatTNer, W.A., Decreased helper $T$ lymphocytes in homosexual men: $I$. Sexual contact in high-incidence areas for the acquired immunodeficiency syndrome. Amer. J. Epidemiol., 121, 629-636 (1985a).

Goedert, J.J., Biggar, R.J., Winn, D.M., ManN, D.L., Strong, D.M., DiGiola, R.A., Grossman, R.J., SANChez, W.C., Kase, R.G., GreENE, M.H., Byar, D.P., Hoover, R.N. and BlatTNER, W.A., Decreased helper $T$ lymphocytes in homosexual men: II. Sexual practices. Amer. J. Epidemiol., 121, 637-644 (1985b).

Goedert, J.J., Sarngadharan, M.G., Biggar, R.J., Weiss, S.H., Winn, D.M., Grossman, R.J., Greene, M.H., Bodner, A.J., ManN, D.L., Strong, D.M., Gallo, R.C. and BlattNER, W.A., Determinants of retrovirus (HTLV-III) antibody and immunodeficiency conditions in homosexual men. Lancet, II, 711-715 (1984).

Grussendorf-Conen, E-I., Deutz, F.J. and de Villiers, E.M., Detection of human papillomavirus-6 in primary carcinoma of the urethra in men. Cancer, 60, 1832-1835 (1987).

Holly, E.A., Whittemore, A.S., Aston, D.A., AhN, D.K., NickOLOFF, B.J. and KRISTIANSEN, J.J., Anal cancer incidence: genital warts, anal fissure or fistula, hemorrhoids, and smoking. J. nat. Cancer Inst., 81, 1726-1731 (1989).

Jablonska, S., Orth, S. and Croissant, O., Cutaneous warts, clinical, histologic, and virologic correlations. Clin. Dermatol., 3, 71-82 (1985).

KASHER, M.S. and RoMAN, A., Characterization of human papillomavirus type $6 \mathrm{~b}$ isolated from an invasive squamous carcinoma of the vulva. Virology, 165, 225-233 (1988).

Koutsky, L.A., Galloway, D.A. and HolmES, K.K., Epidemiology of genital human papillomavirus infection. Epidemiol. Rev., 10, 122-163 (1988).

LoRINCZ, A.T., LANCASTER, W.D. and TEMPLE, G.F., Cloning and characterization of the DNA of a new human papillomavirus from a woman with dysplasia of the uterine cervix. J. Virol., 58, 225-229 (1986).

LoRINCZ, A.T., QUinN, A.P., LANCASTER, W.D. and TeMPLE, G.F., A new type of papillomavirus with cancer of the uterine cervix. Virology, 159, 187-190 (1987).

Muñoz, N., Bosch, X. and Kaldor, J.M., Does human papillomavirus cause cervical cancer? The state of the epidemiological evidence. Brit. $J$. Cancer, 57, 1-5 (1988).

Ostrow, R.S., Manias, D.A., Fong, W.J., Zachow, K.R. and Faras, A.J., A survey of human cancers for human papillomavirus DNA by filter hybridization. Cancer, 59, 429-434 (1987).

Ostrow, R.S., Zachow, K.R., Nimura, M., Okagaki, T., Muller, S., BENDER, M. and FARAS, A.J., Detection of papillomavirus DNA in human semen. Science, 231, 731-733 (1986).

Rando, R.F., Groff, D.E., Chirikjian, J.G. and Lancaster, W.D., Isolation and characterization of a novel human papillomavirus type 6 DNA from an invasive vulvar carcinoma. J. Virol., 57, 353-356 (1986).

RUDLINGER, R. and GROB, R., Papillomavirus infection and skin cancer in renal allograft recipients. Lancet, I, 1132-1133 (1989). 
SChNEIDER, A., Hotz, M. and Gissman, L., Increased prevalence of human papillomavinus in the lower genital tract of pregnant women. Int. $J$. Cancer, 40, 198-201 (1987).

Scholefield, J.H., Sonnex, C., Talbot, I.C., Palmer, J.G. WhatruP, C., MinDEL, A. and NorThOVER, J.M.A., Anal and cervical intraepithelial neoplasia: possible parallel. Lancet, II, 765-769 (1989).

SYRJÄNEN, K.J. and SYRJÄNEN, S.M., Human papillomavirus DNA in bronchial squamous cell carcinomas. Lancet, I, 168-169 (1987).

Wiktor, S.Z., Biggar, R.J., Melbye, M., Ebbesen, P., Colclough, G., DiGioia, R.A., Sanchez, W.C., Grossman, R.J. and Goedert, J.J., Effect of knowledge of human immunodeficiency virus infection status upon sexual activity among homosexual men. J. AIDS, 3, 62-68 (1990).

Young, J.L., PERCY, C.L. and AsIRE, A.J., (eds.), Surveillance, epidemiology and end results. Cancer incidence and mortality in the United States, 1973-77. NCI Monograph, p. 57, NCI, Bethesda (1981).

ZUR HausEN, H., Papillomaviruses in anogenital cancer as a model to understand the role of viruses in human cancers. Cancer Res., 49, 4677$4681(1989 a)$.

zUr Hausen, H., Papillomavirus in anogenital cancer: the dilemma of epidemiologic approaches. J. nat. Cancer Inst., 81, 1680-1682 (1989b). 